\title{
MEWAJIBKAN WALIMATUL 'URS, BATASAN MAHAR DAN SPEKULASI MAHAR DIJADIKAN UANG DAPUR DALAM PERNIKAHAN
}

\author{
Adi Sofyan, M. HI. \\ Sekolah Tinggi Ilmu Syariah (STIS) Al Ittihad Bima \\ Adisofyan.dosen@gmail.com
}

\section{Abstrak}

Hal yang seringkali dikeluhkan oleh sebagian besar kaum adam sebelum pernikahan adalah mahar. Akibat besarnya permintaan mahar dari pihak wanita, tidak jarang pernikahan ditunda bahkan batal dilaksanakan. Harus diakui bahwa mahar adalah memang salah satu syarat wajib yang harus diserahkan oleh calon suami kepada calon istri sebelum menikah. Dibeberapa daerah di Indonesia sendiri, besarnya mahar ditentuntukan oleh tingginya derajat dan pendidikan dari calon istri. Semakin tinggi pendidikan yang capai oleh calon istri, semakin tinggi pula permintaan mahar yang akan diajukan kepada calon suami. Dan ternyata hal seperti ini tidak hanya terjadi di Indonesia, bahkan di negara yang terkenal dengan khazanah keislamannya, sebut saja Mesir. Ternyata walaupun negara ini sangat dikenal sebagai negara yang penghasil ulama yang notabenenya paham akan ilmu agama, juga mengalami hal yang sama terhadap tingginya mahar dalam pernikahan. Maka tidak jarang di negara tersebut banyak ditemukan bujang tua dan perawan tak laku; yang bujang tidak mampu membiayai mahar pernikahan sehingga mengakibatkan banyak wanita yang tidak laku karena tingginya mahar. Saat ini di Indonesia sepertinya, kejadian 
di negara Mesir sedang tumbuh berkembang yang suatu hari nanti tidak menutup kemungkinan akan banyak yang mati sebagai bujang dan perawan. Namun penulis melihat ada perbedaan dari dua negara ini terkait mahar; Indonesia dan Mesir, di Mesir, mahar yang diserahkan oleh calon suami akan sepenuhnya diberikan kepada calon istri dan tidak digunakan untuk sesuatu yang lain. Sedangkan di Indonesia, mahar sering kali digunakan untuk keperluan dapur dan repepsi atau walimatul 'urs, bahkan lebih buruknya adalah tidak sepeserpun yang sampai kepada calon istri. Lalu bagaimana hukumnya jika hal tersebut benar-benar terjadi, dan seberapa besar seharusnya mahar yang dianjurkan oleh Islam untuk meminang calon istri sebelum menikahinya. Inilah yang hendak dijelaskan oleh penulis, dengan harapan memberikan mafaat bagi penulis sendiri dan untuk para pembaca.

\section{Keyword: Mahar, Spekulasi Mahar, Uang Dapur, Pernikahan.}

\section{A. Pendahuluan}

Problematika pernikahan di Indonesia terkait mahar semakin lama semakin menjadi-jadi dan merajalela. Terkadang orang tua tidak tahu dan tidak mau tahu bagaimana dan seperti apa posisi calon suami bagi anak gadisnya. Kalau seandainya pihak laki-laki berasal dari golongan kaya dan mampu dalam hal material maka mahar yang tinggi bukanlah sebuah masalah besar, namun ketika datang dari golongan pas-pasan yang mungkin dikategorikan tidak mampu, maka sudah seharusnya seorang orang tua paham dan mengerti bagaimana dan seberapa banyak mahar yang harus diminta kepada calon suami bagi anaknya.

Tingginya mahar, tidak serta merta menjadikan posisi dan kedudukan keluarga menjadi lebih mulia dimata manusia 
maupun dalam pandangan Allah Swt., sebaliknya rendahnya mahar tidak menjadikan kedudukan menjadi lebih rendah. Maka tidak heran Rasul Saw., dalam haditsnya menganjurkan dalam memilih pasangan yang dikedepankan adalah agamanya karena dengan agama yang ada dalam diri inilah kedudukan seseorang menjadi lebih mulia dan tinggi derajatnya dimata manusia dan dihadapan Allah Swt.:

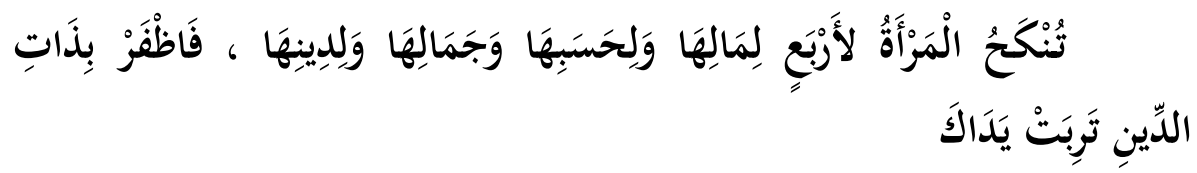

Artinya:

"Wanita dinikahi karena empat hal; karena hartanya, keturunannya, kecantikannya, dan agamanya. Maka pilihlah karena agamanya niscaya engkau akan beruntung." (HR. Al Bukhari dan Muslim)

Demikian dengan ayat Allah yang mendukung dan menguatkan hadits ini:

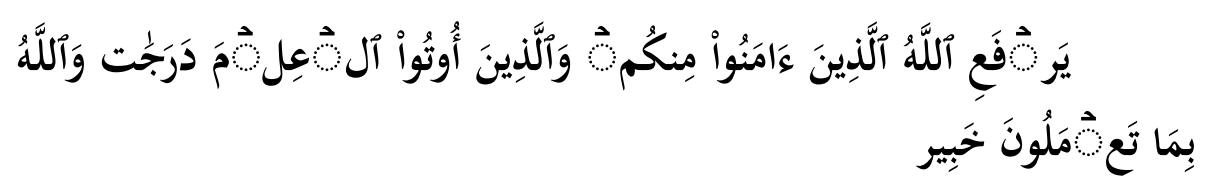

Terjemahnya:

"Allah akan meninggikan orang-orang yang beriman di antaramu dan orang-orang yang diberi ilmu pengetahuan beberapa derajat. Dan Allah Maha Mengetahui apa yang kamu kerjakan." (QS. Al Mujadilah: 11)

Dengan Ilmu, seseorang akan dengan mudah meraih kedudukan dunia dan akhirat, serta dengan iman seseorang akan meraih derajat takwa. Maka inilah yang tidak dipercayai dan hilang ditengah masyarakat Indonesia saat ini, dimana materi dan harta lebih tinggi derajat dan kedudukannya dibanding ilmu dan iman. Sehingga ketika dua calon untuk

Sangaji Jurnal Pemikiran Syariah dan Hukum 
anak gadis datang melamar, yang satu berilmu dan beriman dan yang lain berharta dan berkedudukan, yang kedua inilah yang akan dipilih walaupun tidak berilmu dan beriman.

Hal menarik lain dari acara pernikahan di Indonesia khususnya saat ini adalah mengatasnamakan mahar dalam urusan dapur. Uang mahar yang seharusnya diserahkan kepada calon istri digunakan untuk keperluan dapur acara walimatul 'urs atau acara lain yang bersifat menghamburkan uang. Sehingga setelah acara selesai, sang istri dibawa oleh sang suami dalam keadaan kosong dan hampa tampa memilki apa-apa karena semua telah habis digunakan untuk keperluan acara dan lain-lain. Alasan yang dikemukakan sederhana, kalau bukan uang mahar, mau dapat uang dari mana lagi.

Sebenarnya pernikahan dalam Islam adalah sesuatu yang sederhana dan Nabi Saw.-pun tidak pernah memerintahkan para sahabat dan umatnya untuk terlalu membesar-besarkan acara walimatul 'urs.

\section{أَوْلِلْ وَلَوْ بِشَاةٍِ}

Artinya:

"Adakanlah walimah walau dengan seekor kambing" (HR. Al Bukhari, Muslim, al Timidzi, Al nasa'i, Abu Daud, Ibnu Majah, Ahmad, Imam Malik, dan Al Darimi) Bahkan jumhur ulama (mayoritas ulama) sepakat bahwa perintah mengadakan walimah ini bersifat sunnah, tidak wajib. Artinya bagi yang mampu saja, sedang bagi yang tidak mampu maka cukupkan dengan acara akad dan ijab qabul.

Akibat terlalu mengedepankan walimah bahkan sampai mewajibkan, berapa banyak yang harus dikorbankan; pernikahan harus ditunda atau bahkan batal sama sekali, anakanak yang sudah seharusnya berkeluarga kembali melajang yang pada akhirnya terjadilah yang harusnya tidak boleh terjadi (berzina hingga hamil di luar nikah), belum lagi anak 
gadis dianggap tidak laku dan banyak lagi perihal lain yang memang seharusnya tidak boleh terjadi.

\section{B. Pengertian}

\section{Walimatul 'Urs}

Kata walimah sebenarnya berasal dari bahasa arab

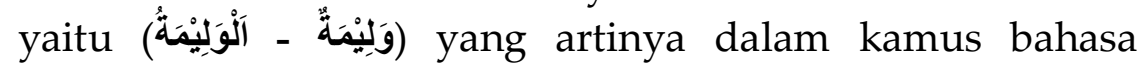
Indonesia perjamuan kawin atau akad nikah. ${ }^{1}$ Dalam kitab Al Ta'rifat al Fiqhiyat dijelaskan bahwa arti walimah adalah makanan pengantin pada pesta perkwinan atau semua makanan yang dihidangkan untuk mengundang tamu atau yang lainnya. ${ }^{2}$ Sedangkan 'urs juga berasal dari bahasa arab (ألَعُرْنُ - عُرْسُسن) yang artinya pasangan pengantin, laki-laki dan perempuan. $^{3}$

Apabila dua kata tersebut digabungkan, walimatul 'urs (وَلَيْيَةُ آلَعُرْسنُ) akan bermakna jamuan atas pernikahan pasangan pengantin.

Secara garis besar, walimah terbagi menjadi dua bagian: ${ }^{4}$

a) Walimah yang ditetapkan oleh Syari'at, seperti walimatul 'urs, walimatu ta'ziyah atau walimatul aqiqah.

b) Walimah berdasarkan adat yang berlaku dalam sebuah masyarakat yang bertujuan menampakkan

1 Tim Pusat Bahasa Depdiknas. 2008. Kamus Bahasa Indonesia. Jakarta: Pusat Bahasa Departemen Pendidikan Nasional. Hlm. 1615.

2 Muhammad Amim al Ihsan al Mujadidi al Barkati. 2003. Al Ta'rifat al Fiqhiyat. Cetakan I. Bairut: Dar al Kurub al alamiyah. Hlm. 240.

${ }^{3}$ Muhammad Amim al Ihsan al Mujadidi al Barkati. 2003. Al Ta'rifat al Fiqhiyat. Cetakan I. Bairut: Dar al Kurub al alamiyah. Hlm. 140.

4 Ibnu Mas'ud. 2019. Kajian Tentang Macam-Macam Walimah (Resepsi/Tasyakuran). $\quad$ Diakses $25 \quad$ September 2019. http://mwcnucipayung.blogspot.com/2019/09/kajian-tentang-macam-macamwalimah.html

Sangaji Jurnal Pemikiran Syariah dan Hukum 
kegembiraan/rasa syukur. Untuk walimah ini ada banyak macam dan bentuknya, seperti:

1) Walimatul I'dzar: Walimah yang diadakan atas dasar khitanan.

2) Walimatul Wakirah: Walimah yang diadakan atas dasar membangun rumah.

3) Walimatul Naqi'ah: Walimah yang diadakan atas dasar kedatangan seseorang dari bepergian.

4) Walimatul $M a^{\prime}$ dabah: Walimah yang diadakan tanpa sebab. Bila undangan walimah tersebut mencakup semua lapisan masyarakat dinamakan Jafla, bila hanya sebatas kalangan tertentu saja dinamakan Naqra.

\section{Mahar}

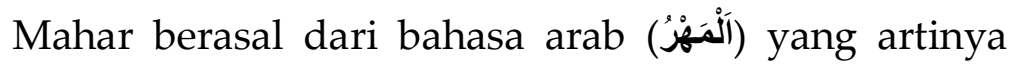
pemberian berupa mas, uang, dan sebagainya dari mempelai laki-laki kepada pengantin perempuan pada waktu nikah; mas kawin. ${ }^{5}$ Secara istilah mahar juga diartikan sebagai sebagai harta yang menjadi hak istri dari suaminya dengan adanya akad atau dukhul. ${ }^{6}$ Atau suatu pemberian yang diwajibkan bagi calon suami kepada calon istrinya, baik dalam bentuk benda ataupun dalam bentuk jasa (memerdekakan, mengajar, dan lain sebagainya). ${ }^{7}$

5 Tim Pusat Bahasa Depdiknas. 2008. Kamus Bahasa Indonesia. Jakarta: Pusat Bahasa Departemen Pendidikan Nasional. Hlm. 895.

6 Amirur Nurudin. 2004. Hukum Perdata Islam di Indonesia. Jakarta: Prenada Media. Hlm. 54.

7 Tihami dan Sohari Sahrani. 2009. Fiqih Munakahat. Jakarta: PT Raja Gravindo Persada. Hlm. 37. 
Para ulama madzhab berbeda pendapat dalam mendefinisikan mahar, dengan ungkapan-ungkapan sebagai berikut: ${ }^{8}$

a) Mazhab Hanafi mengatakan bahwa mahar adalah sejumlah harta yang menjadi hak istri karena akad pernikahan sehingga dibolehkannya terjadi senggama.

b) Mazhab Maliki mengartikan mahar adalah sebagai sesuatu yang menjadikan halal untuk digauli.

c) Mazhab Hambali mendefinisikan mahar adalah seabagai imbalan suatu perkawinan baik disebutkan secara jelas dalam akad nikah maupun ditentukan setelah akad dengan persetujuan kedua belah pihak.

d) Abdurrahman Al Jaziri mengatakan bahwa mahar adalah pemberian wajib dari suami kepada istrinya sebagai barter diperbolehkannya bersenang-senang

Ulama fikih sepakat bahwa mahar itu ada dua macam, yaitu: ${ }^{9}$

a) Mahar Musamma

Mahar Musamma, yaitu mahar yang sudah disebut atau dijanjikan kadar dan besarnya ketika akad nikah. Atau mahar yang dinyatakan kadarnya pada waktu akad nikah.

b) Mahar Mitsli (Sepadan)

Mahar Mitsli yaitu mahar yang tidak disebut besar kadarnya pada saat sebelum ataupun ketika terjadi pernikahan. Atau mahar yang diukur (sepadan) dengan mahar yang pernah diterima oleh keluarga terdekat,

8 Zurifah Nurdin. 2016. Aksiologi Hadis Ahkam Tentang Mahar. El-Afkar Volume 5 Nomor II, Juli - Desember 2016. Hlm. 25. Lihat juga: Abdurahman Aljaziri. 1990. Al Figh ala Madzahibi al Arba'ah. (Bairut: Dar al Kutub al Islamiyah. Hlm. 89.

${ }^{9}$ M. Abdul Mujid dkk. 1995. Kamus Istilah Fikih. Jakarta: Pustaka Firdaus. Hlm. 185.

Sangaji Jurnal Pemikiran Syariah dan Hukum 
agak jauh dari tetangga sekitarnya, dengan memerhatikan status sosial, kecantikan, dan sebagainya.

\section{Dasar Hukum}

\section{Walimatul 'Urs}

Seperti yang disebutkan bahwa pada hakikatnya walimatul 'urs bersifat sunnah menurut mayoritas ulama ${ }^{10}$, itupun bagi yang mampu melaksanakannya. Namun dalam prakteknya, khususnya di Indonesia hal ini sudah menjadi seakan sebuah kewajiban yang harus diadakan dan menjadi ajang untung saling pamer kebesaran dan harta. Sedangkan akad yang mestinya menjadi sebuah kewajiban dan kegiatan inti dari sebuah pernikahan kadang dianggap sunnah dan remeh bahkan menjadikannya bahan canda tawa ketika proses ijab qabul berlangsung.

Adapun dalil atau dasar hukum yang memerintahkahkan untuk mengadakan walimatui 'urs adalah hadits riwayat al Tirmidzi:

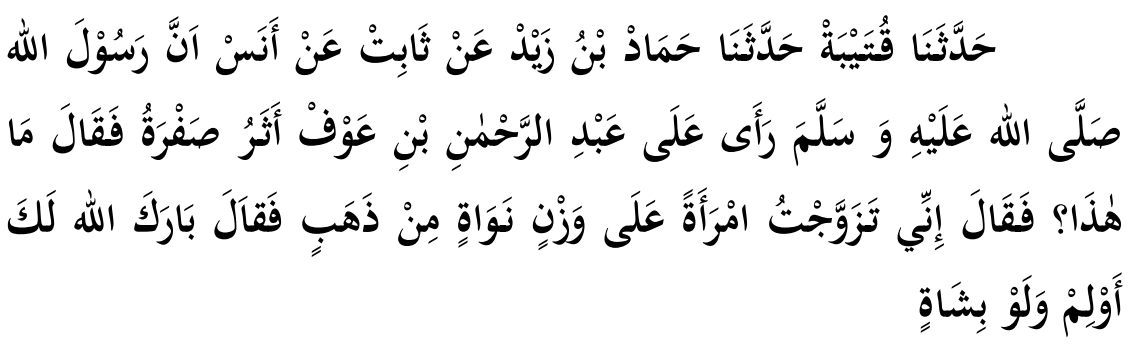

Artinya:

Qutaibah menceritakan pada kami, Hammad bin Zaid dari Tsabit menceritakan dari Anas; Sesungguhnya Rasulullah SAW telah melihat pada Abdurrahman bin Auf bekas kekuning-kuningan, lalu beliau bertanya: "Apa ini?" Berkata Abdurraman bin Auf: "Sesungguhnya saya telah

10 Taqiyudin Abi Bakar. Kifayatul Ahyar, Juz II. Semarang: CV. Toha Putra. Hlm. 68. 
kawin dengan seorang wanita dengan maskawin seberat biji kurma dari emas", lalu Rasulullah bersabda: "Semoga Allah memberkatimu, adakanlah walimah meskipun hanya seekor kambing." (H.R Tirmidzi)

\section{Mahar}

Berbeda halnya dengan mahar, mahar adalah sesuatu yang memang diwajibkan dan harus diserahkan oleh calon suami kepada calon istri sebelum akad nikah atau ijab qabul dilangsungkan. Dalil dan dasar hukum tentang wajibnya mahar ini ada dalam Al Quran, Hadits maupun Ijma' para ulama:

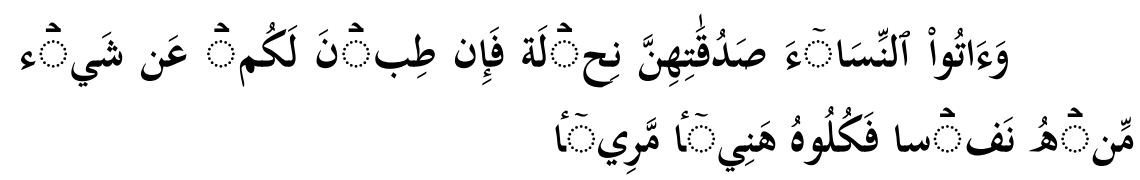

Terjemahnya:

"Berikanlah maskawin (mahar) kepada wanita (yang kamu nikahi) sebagai pemberian dengan penuh kerelaan. Kemudian jika mereka menyerahkan kepada kamu sebagian dari maskawin itu dengan senang hati, maka makanlah (ambillah) pemberian itu (sebagai makanan) yang sedap lagi baik akibatnya" (QS. Al Nisa': 4)

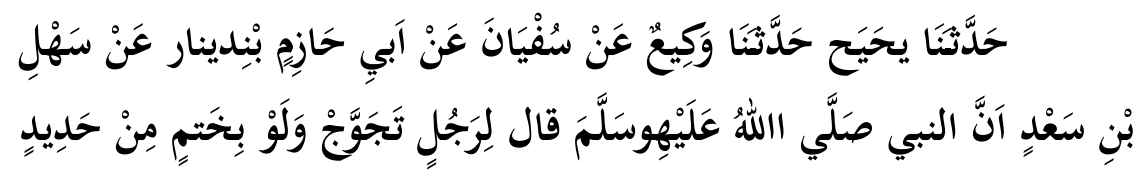

Artinya:

Telah berkata Yahya, telah berkata Waqi' dari Sufyan dari Abi Hazim bin Dinar dari Sahal bin Said al Sa'idi bahwa Nabi Saw. bersabda: "Hendaklah seorang menikah meskipun (hanya dengan mahar) sebuah cincin yang terbuat dari besi." (HR Bukhari).

Sedangkan menurut ketetapan dalil dari Ijma' menyatakan bahwa: para ulama telah bersepakat bahwa 
mahar wajib hukumnya tanpa adanya perselisihan (khilaf), ketetapan itu di sepakati oleh para ulama, baik ulama generasi pertama Islam hingga masa sekarang. ${ }^{11}$

\section{Mewajibkan Acara Walimatul 'urs}

Untuk menetapkan hukum sebuah perkara dalam ilmu fikih para ulama tidak menilai dan menentukan dengan hanya melihat dari satu sisi permasahalan dengan mengaitkannya dengan dalil-dalil nash. Lebih dari itu segala bentuk usaha dan pemikiran para ulama fikih ini tumpahkan walaupun hanya pada satu perkara masalah. Hal ini karena hasil ijtihad dan fatwa tersebut tidak hanya akan dilihat dan digunakan oleh segelintir manusia. Artinya jika terjadi kesalahan, maka akan sangat fatal-lah akibatnya. Bisa dibayangkan kalau seandainya Imam Syafi'i salah dalam berfatwa atau berijtihad, maka orang Islam seluruh dunia (kususnya yang bermadzhab Syafi'i) akan banyak terjerumus dalam kesesatan.

Demikian dalam menetapkan hukum walimatul 'urs ini, penulis tidak mengatakan bahwa masyarakat merubah hukum walimatul 'urs yang awalnya sunnah menjadi wajib, namun tidakan dan praktek yang terjadi ditengah masyarakat saat ini seakan-akan menganggap bahwa tampa walimatul 'urs, pernikahan tidak sah atau tidak diakui, dan ini jelas salah.

Jika berdalih dengan adat dan kebiasaan yang ada, maka hukum adat atau kebiasaan-pun memiliki aturan dan kaidah, seperti tidak boleh bertentangan dengan hukum syariah (Allah dan Rasul-Nya). Alangkah malang dan terpuruknya nasib si miskin yang tidak bisa membiayai pernikahan anak dan menantunya kalau hal seperti terus berlanjut. Bahkan tidak hanya sampai disini, penundaan dan pembatalan pernikahan

11 Muhammad Zuhaily. 2003. Fiqih Munakahat Kajian Fiqih Pernikahan dalam Perspektif Madzhab Syafi'i. Terj. Mohammad Kholison. Surabaya: CV. Imtiyaz. Hlm. 235. 
akibat besarnya biaya akan mengakibatkan penyebaran maksiat perzinahan dimana-mana.

\section{E. Batasan Mahar}

Dalam beberapa literatur, baik dari ayat dalam $\mathrm{Al}$ Quran, hadits-hadits Rasulullah Saw. dan beberapa kitab karya ulama-ulama besar, penulis belum menemukan secara spesifik tentang pembatasan tertinggi pemberian mahar menurut hukum Islam dalam pernikahan. Hal ini sebagaimana dalam firman Allah Swt.:

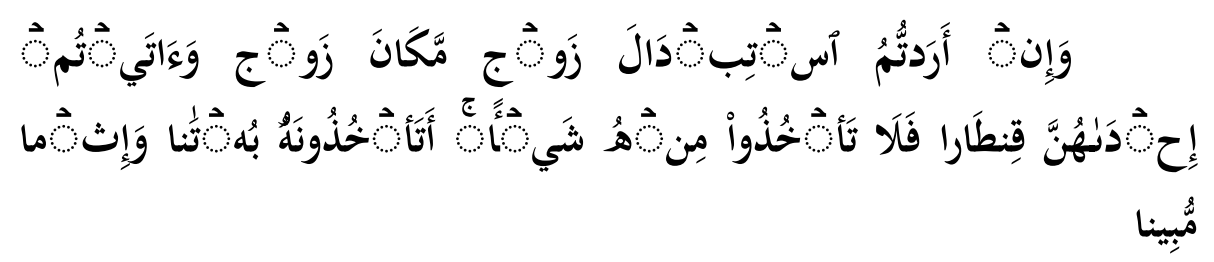

Terjemahnya:

"Dan jika kamu ingin mengganti isterimu dengan isteri yang lain, sedang kamu telah memberikan kepada seseorang di antara mereka harta yang banyak, maka janganlah kamu mengambil kembali dari padanya barang sedikitpun. Apakah kamu akan mengambilnya kembali dengan jalan tuduhan yang dusta dan dengan (menanggung) dosa yang nyata?." (QS. Al Nisa': 20)

Kendatipun demikaian, ditemukan beberapa syarat mahar yang hendak diserahkan oleh calon suami kepada calon istri sebagai dikuti oleh Jaih Mubarak dalam kitabnya "Fikih Munakahat": ${ }^{12}$

1. Harta berharga. Tidak sah mahar dengan yang tidak berharga walaupun tidak ada ketentuan banyak atau sedikitnya mahar, mahar sedikit tapi bernilai tetap sah disebut mahar.

12 Putra Halomoan. 2015. Penetapan Mahar Terhadap Kelangsungan Pernikahan Ditinjau Menurut Hukum Islamjuris. Volume 14, Nomor 2 JuliDesember 2015. Hlm. 111.

Sangaji Jurnal Pemikiran Syariah dan Hukum 
2. Barangnya suci dan bisa diambil manfaatnya. Tidak sah mahar dengan memberikan khamar, babi, atau darah, karena semua itu haram dan tidak berharga/suci.

3. Barangnya bukan barang ghasab. Ghasab artinya mengambil barang orang lain tanpa seizinnya namun tidak bermaksud untuk memilikinya karena berniat untuk mengembalikannya kelak. Memberikan mahar dengan barang ghasab tidak sah.

4. Bukan barang yang tidak jelas keadaannya. Tidak sah mahar dengan barang yang tidak jelas keadaannya, atau tidak disebutkan jenisnya.

Hanya saja terjadi silang pendapat antara ulama fikih (madzhab) terkait batasan rendah pemberian mahar: ${ }^{13}$

1. Mazhab Hanafi berpendapat, standar mahar yang paling rendah adalah sepuluh dirham, standar ukuran mahar diqiyaskan kepada ukuran pencurian, yaitu yang membuat tangan si pencuri dipotong. Menurut mereka, yaitu pencurian dalam jumlah satu dinar atau sepuluh dirham, untuk menampakkan posisi perempuan. ${ }^{14}$ Tetapi ketika mereka mencari "dasar" untuk mengqiyaskan batas maksimal dan minimal mahar, yang mirip ialah dasar hukuman potong tangan dalam kasus pencurian, karena kedua hukum ini sama-sama memberikan kewenangan untuk memperolah manfaat pada anggota tubuh dengan imbalan harta, yaitu potong tangan karena melakukan pencurian terhadap harta yang sudah mencapai satu nisab dan menggauli dengan imbalan berupa mahar. Sedangkan perbedaannya sangat mencolok, dan qiyas seperti ini

13 Burhanuddin A. Gani dan Ainun Hayati. 2017. Pembatasan Jumlah Mahar Melalui Keputusan Musyawarah Adat Kluet Timur. Jurnal Hukum Keluarga dan Hukum Islam Volume 1 Nomor 1, Januari-Juni 2017. Hlm. 185-186.

14 Lihat: Wahbah Al Zuhaili. 2007. Fiqih Islam Waadillatuhu, Jilid 9. Jakarta: Gema Insani. Hlm. 235-236. 
dianggap lemah. Disebabkan hukuman potong tangan sangat berbeda dengan menggauli. ${ }^{15}$

2. Mazhab Maliki berpendapat, standar mahar yang paling rendah adalah seperempat dinar atau tiga dirham perak murni yamg sama sekali tidak mengandung kepalsuan. Atau dengan barang-barang yang suci dan terbebas dari najis yang sebanding dengan harganya, yang berupa barang, atau hewan, atau bangunan yang dibeli dengan secara legal, dan bermanfaat menurut syariat. Maksudnya, boleh dimanfaatkan, bukan seperti peralatan hiburan. Juga mampu diserahkan kepada istri, yang kadar, jenis, dan macamnya jelas.

3. Mazhab Syafi'i dan Hambali berpendapat, tidak ada batasan terendah bagi mahar. Sahnya mahar tidak ditentukan dengan sesuatu. Oleh karena itu, sah jika mahar adalah harta yang sedikit ataupun banyak. Batasannya adalah, semua yang sah untuk dijual atau yang memiliki nilai sah untuk menjadi mahar. Dan yang tidak memilki nilai maka tidak bisa dijadikan mahar, selama tidak sampai kepada batasan yang tidak bisa dinilai.

Adapun faktor penyebab perbedaan pendapat tentang kadar (ketentuan mahar) di kalangan ulama madzhab ada dua macam sebagaimana disebutkan oleh Ibn Rusyd, yaitu: ${ }^{16}$

1. Ketidakjelasan akad nikah itu sendiri antara kedudukannya sebagai salah satu jenis pertukaran, karena yang dijadikan adalah kerelaan menerima ganti, baik sedikit maupun

${ }^{15}$ Lihat: Ibnu Rusd. 2013. Bidayatu al Mujtahid wa Nihayatu al Muqtashid. Jakarta timur: Ak Barmedia. Hlm. 83.

16 Putra Halomoan. 2015. Penetapan Mahar Terhadap Kelangsungan Pernikahan Ditinjau Menurut Hukum Islamjuris. Volume 14, Nomor 2 JuliDesember 2015. Hlm. 113. Lihat juga: Burhanuddin A. Gani dan Ainun Hayati. 2017. Pembatasan Jumlah Mahar Melalui Keputusan Musyawarah Adat Kluet Timur. Jurnal Hukum Keluarga dan Hukum Islam Volume 1 Nomor 1, Januari-Juni 2017. Hlm. 186.

Sangaji Jurnal Pemikiran Syariah dan Hukum 
banyak, seperti halnya dalam jual beli dan kedudukannya sebagai ibadah yang sudah ada ketentuannya. Demikian itu kalau ditinjau dari segi bahwa dengan mahar itu lakilaki dapat memiliki jasa wanita itu selamanya, maka perkawinan itu mirip dengan pertukaran. Tetapi ditinjau dari segi adanya larangan mengadakan persetujuan untuk meniadakan mahar, maka mahar itu mirip dengan ibadah.

2. Adanya pertentangan antara qiyas yang menghendaki adanya pembatasan mahar dengan mafhum hadits yang tidak menghendaki adanya pembatasan. Qiyas yang menghendaki adanya pembatasan mahar adalah seperti pernikahan itu ibadah, sedangkan ibadah itu sudah ada ketentuannya.

\section{F. Spekulasi Mahar}

Ada sebuah kebiasaan yang sering terjadi dalam kehidupan masyarakat, menggunakan uang mahar atau mengatas namakan mahar sebagai uang untuk keperluan dapur dalam acara pernikahan. Artinya menganggap uang mahar adalah uang dapur atau uang dapur adalah sama dengan uang mahar. Sehingga mahar berupa uang yang seharusnya diserahkan kepada calon istri digunakan untuk berbagai macam keperluan oleh orang tua calon istri tampa di ganti sama sekali, bahkan tampa pemberitahuan terlebih dahulu.

Spekulasi seperti ini, menurut penulis terjadi karena beberapa sebab, diantaranya:

1. Kurangnya pengetahuan agama, sehingga beranggapan demikian, akhirnya terus berlanjut dari generasi ke generasi.

2. Kurangnya persiapan yang dilakukan sebelum acara pernikahan, sehingga terkesan memudahkan dengan menggunakan uang mahar. 
3. Menganggap segala persiapan pernikahan adalah tanggaung jawan calon suami, sehingga menganggap uang mahar adalah dana pernikahan.

4. Menganggap walimatul 'urs adalah acara inti pernikahan, sehingga mengorbankan uang mahar adalah sesuatu yang wajar.

5. Perasaan malu jika acara yang diadakan terkesan kecil dan tidak berwibawa.

Sejatinya, mahar berupa uang atau harta yang lain adalah hal milik anak gadis yang akan menikah, bukan berarti orang tua dengan mudah mengambil dan menggunakannya, terlebih tampa pemberitahuan terlebih dahulu. Hal semacam ini, sedari awal sudah seharusnya tidak terjadi dan membiasakan kepada anak keturunan. Karena seorang anak, terlebih pada saat akan menikah tidak mungkin menolak ketika maharnya akan digunakan apalagi untuk kepentingan pernikahannya.

Mahar yang diserahkan oleh calon suami adalah modal awal bagi calon istri dalam mengarungi kehidupan berkeluarga. Dengan uang mahar tersebut, sang istri bisa memulai usaha terlebih apabila tidak bekerja karena kurangnnya pendidikan pada masa remaja. Oleh sebab itu, spekulasi semacam ini tidak seharusnya terjadi bahkan bisa masuk ke dalam kategori sesuatu yang diharamkan. Allah berfirman:

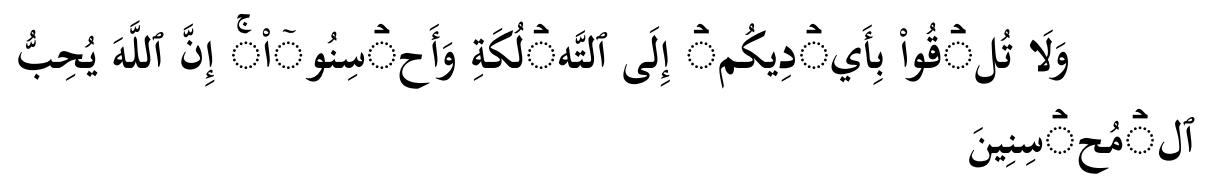

Terjemahnya:

"Dan janganlah kamu menjatuhkan dirimu sendiri ke dalam kebinasaan, dan berbuat baiklah, karena sesungguhnya Allah menyukai orang-orang yang berbuat baik." (QS. Al Baqarah: 195)

Sangaji Jurnal Pemikiran Syariah dan Hukum 
Ayat ini menjelaskan larangan Allah Swt. agar tidak menjerumuskan diri dalam kebinasaan. Mengorbankan sesuatu yang besar (masa depan keluarga) demi sesuatu yang tidak diwajibkan (mahar: hukumnya sunnah hanya bagi yang mampu), maka sama dengan menjerumuskan diri dalam kerusakan yang akan menyebabkan kehancuran dan penyesalan pada akhirnya. Dalam kaidah fikih-pun disebutkan:

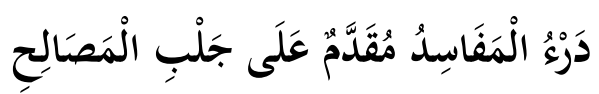

Artinya:

"Meninggalkan sesuatu yang buruk, lebih dikedepankan dari pada mengerjakan sesuatu yang baik."

\section{G. Kesimpulan}

Dari penjelasan di atas ditarik beberapa kesimpulan, bahwa:

1. Tidak ada perbedaan pendapat para ulama fikih terkait batas tertinggi untuk mahar dalam pernikahan. Perbedaan hanya terjadi pada batas terendah seseorang memberikan mahar untuk pasangan atau calon istrinya.

2. Terjadinya spekulasi uang mahar dalam pernikahan untuk pembiayaan walimatul 'urs secara umumnya adalah salah bahkan bisa terjerumus dalam perbuatan yang diharamkan. 


\section{Daftar Pustaka}

Depdiknas, Tim Pusat Bahasa. 2008. Kamus Bahasa Indonesia. Jakarta: Pusat Bahasa Departemen Pendidikan Nasional.

Amim, Muhammad al Ihsan al Mujadidi al Barkati. 2003. Al Ta'rifat al Fiqhiyat. Cetakan I. Bairut: Dar al Kurub al alamiyah.

Nurudin, Amirur. 2004. Hukum Perdata Islam di Indonesia. Jakarta: Prenada Media.

Sahrani, Tihami dan Sohari. 2009. Fiqih Munakahat. Jakarta: PT Raja Gravindo Persada.

Nurdin, Zurifah. 2016. Aksiologi Hadis Ahkam Tentang Mahar. ElAfkar Volume 5 Nomor II, Juli - Desember 2016.

Aljaziri, Abdurahman. 1990. Al Figh ala Madzahibi al Arba'ah. (Bairut: Dar al Kutub al Islamiyah.

Mujid, M. Abdul dkk. 1995. Kamus Istilah Fikih. Jakarta: Pustaka Firdaus.

Bakar, Taqiyudin Abi. Kifayatul Ahyar, Juz II. Semarang: CV. Toha Putra.

Zuhaily, Muhammad. 2003. Fiqih Munakahat Kajian Fiqih Pernikahan dalam Perspektif Madzhab Syafi'i. Terj. Mohammad Kholison. Surabaya: CV. Imtiyaz.

Halomoan, Putra. 2015. Penetapan Mahar Terhadap Kelangsungan Pernikahan Ditinjau Menurut Hukum Islamjuris. Volume 14, Nomor 2 Juli-Desember 2015.

A. Gani, Burhanuddin dan Ainun Hayati. 2017. Pembatasan Jumlah Mahar Melalui Keputusan Musyawarah Adat Kluet Timur. Jurnal Hukum Keluarga dan Hukum Islam Volume 1 Nomor 1, Januari-Juni 2017.

Al Zuhaili, Wahbah. 2007. Fiqih Islam Waadillatuhu, Jilid 9. Jakarta: Gema Insani.

Rusd, Ibnu. 2013. Bidayatu al Mujtahid wa Nihayatu al Muqtashid. Jakarta timur: Ak Barmedia.

Sangaji Jurnal Pemikiran Syariah dan Hukum 
Mas'ud, Ibnu. 2019. Kajian Tentang Macam-Macam Walimah (Resepsi/Tasyakuran). Diakses 25 September 2019. http://mwcnucipayung.blogspot.com/2019/09/kajiantentang-macam-macam-walimah.html 